\title{
Remote Sensing in Coastline Detection
}

\author{
Donatella Dominici * (1D and Sara Zollini $(\mathbb{D}$ \\ DICEAA-Department of Civil, Construction-Architecture and Environmental Engineering, \\ University of L'Aquila, Via Gronchi 18,67100 L'Aquila, Italy; sara.zollini@graduate.univaq.it \\ * Correspondence: donatella.dominici@univaq.it
}

Received: 1 June 2020; Accepted: 24 June 2020; Published: 7 July 2020

"Is beach erosion a natural cycle or is it getting worse with rising sea levels?" [1]

Coastal zones are some of the most populated and developed areas in the world.

They have rich biodiversity and it is said that more than $45 \%$ of the world's population lives there [2].

Coastal areas provide many resources but they are very vulnerable environments. Coastal hazards (e.g., typhoons/cyclones/hurricanes, storm surges, tsunamis) represent significant threats to the population, infrastructure and to the coasts themselves. There are also other hazards which are not visible or produce long-term effects, such as rising sea levels and coastal erosion.

Beach erosion is defined as the removal of sand from a beach to deeper water offshore or alongshore into inlets, tidal shoals and bays [1]. This is caused by various factors, including natural and anthropological factors such as the simple inundation of the land by rising sea levels resulting from the melting of the polar ice caps.

Climate change is one of the main reasons for this, but it is not the only one. Beaches are greatly influenced by the frequency and magnitude of storms along a particular shoreline.

Data on shoreline changes for the period between 1984 and 2016 (33 years) show that $24 \%$ of the world's sandy beaches are eroding at rates exceeding $0.5 \mathrm{~m} / \mathrm{yr}$, while $28 \%$ are accreting and $48 \%$ are stable. Moreover, the majority of the sandy shorelines in marine protected areas are eroding [3].

It is clear that the coastal environment needs to be protected, not only for heritage but also to preserve human life.

For the management of coastal areas, prevention assumes a central role. The protection of coastal green belts as well as the shoreline through coastal dykes or other hard infrastructures should be based on a carefully performed risk analysis. On the other hand, "softer" components, such as coastal watching and monitoring, are also important to aid the preservation of these areas [2]. In this sense, remote sensing takes on a fundamental role in "watching" and detecting coastal changes over time.

With the latest generation of high and very high resolution satellite images, it is possible to monitor a wide area of land at relatively low costs. Of course, there are many methods that can be used and that has been used in the literature to detect the coastal environment, like GNSS (Global Navigation Satellite System), UAV (Unmanned Aerial Vehicle) photogrammetry, video systems, traditional surveys using total station, levelling and so on, but remote sensing, compared to the others, is quicker, the images cover a larger portion of the territory, there is no need to go physically to the place under investigation and there is no need for an "ad hoc" flight. It is obvious that the synergy of all these techniques would allow researchers to reach more complete results; indeed, in most applications, satellite remote sensed images are not used alone. However, thanks to the arrangement of high-performance image analysis techniques, it is nowadays possible to at least obtain initial results about the problem to be solved.

To conclude, the main goal is to find an automated and replicable technique to evaluate the spatial and temporal evolution of alterations due to natural and anthropogenic events, especially for large areas, so that prompt action can be initiated. 
I am grateful to all the colleagues who played a role in the drafting of this Special Issue [4-10], as they have allowed a good overview of all multiscale remote sensing techniques (high resolution images, photogrammetry, SAR (Synthetic Aperture Radar), GNSS, etc.) and a whole array of methods and techniques for the processing, analysis and discussion of multitemporal remotely sensed data.

Author Contributions: D.D. and S.Z. contributed equally to this work. Both authors have read and agreed to the published version of the manuscript.

Funding: This research received no external funding.

Acknowledgments: I would like to thank MDPI and above all Esme Wang for her patience and the support.

Conflicts of Interest: The authors declare no conflict of interest.

\section{References}

1. 'What Causes Beach Erosion?', Scientific American. Available online: https://www.scientificamerican.com/ article/what-causes-beach-erosion/ (accessed on 21 April 2020).

2. Rajib, S. 'Chapter 1-Global Coasts in the Face of Disasters'. In Coastal Management; Krishnamurthy, R.R., Jonathan, M.P., Srinivasalu, S., Glaeser, B., Eds.; Elsevier: Amsterdam, The Netherlands, 2019; pp. 1-4.

3. Luijendijk, A.; Hagenaars, G.; Ranasinghe, R.; Baart, F.; Donchyts, G.; Aarninkhof, S. 'The State of the World's Beaches'. Sci. Rep. 2018, 8, 6641. [CrossRef] [PubMed]

4. Anzidei, M.; Doumaz, F.; Vecchio, A.; Serpelloni, E.; Pizzimenti, L.; Civico, R.; Greco, M.; Martino, G.; Enei, F. Sea Level Rise Scenario for 2100 A.D. in the Heritage Site of Pyrgi (Santa Severa, Italy). J. Mar. Sci. Eng. 2020, 8, 64. [CrossRef]

5. Zanutta, A.; Lambertini, A.; Vittuari, L. UAV Photogrammetry and Ground Surveys as a Mapping Tool for Quickly Monitoring Shoreline and Beach Changes. J. Mar. Sci. Eng. 2020, 8, 52. [CrossRef]

6. Zollini, S.; Alicandro, M.; Cuevas-González, M.; Baiocchi, V.; Dominici, D.; Buscema, P.M. Shoreline Extraction Based on an Active Connection Matrix (ACM) Image Enhancement Strategy. J. Mar. Sci. Eng. 2020, 8, 9. [CrossRef]

7. Alicandro, M.; Baiocchi, V.; Brigante, R.; Radicioni, F. Automatic Shoreline Detection from Eight-Band VHR Satellite Imagery. J. Mar. Sci. Eng. 2019, 7, 459. [CrossRef]

8. Trembanis, A.; Abla, A.; Haulsee, K.; DuVal, C. Benthic Habitat Morphodynamics-Using Remote Sensing to Quantify Storm-Induced Changes in Nearshore Bathymetry and Surface Sediment Texture at Assateague National Seashore. J. Mar. Sci. Eng. 2019, 7, 371. [CrossRef]

9. Immordino, F.; Barsanti, M.; Candigliota, E.; Cocito, S.; Delbono, I.; Peirano, A. Application of Sentinel-2 Multispectral Data for Habitat Mapping of Pacific Islands: Palau Republic (Micronesia, Pacific Ocean). J. Mar. Sci. Eng. 2019, 7, 316. [CrossRef]

10. Pugliano, G.; Robustelli, U.; Di Luccio, D.; Mucerino, L.; Benassai, G.; Montella, R. Statistical Deviations in Shoreline Detection Obtained with Direct and Remote Observations. J. Mar. Sci. Eng. 2019, 7, 137. [CrossRef]

(C) 2020 by the authors. Licensee MDPI, Basel, Switzerland. This article is an open access article distributed under the terms and conditions of the Creative Commons Attribution (CC BY) license (http://creativecommons.org/licenses/by/4.0/). 